Fall 2005

\title{
The Janus Face of Brussels: Socialization and Everyday Decision Making in the European Union
}

Jeffrey Lewis

Cleveland State University, j.lewis07@csuohio.edu

Follow this and additional works at: https://engagedscholarship.csuohio.edu/clpolsci_facpub

How does access to this work benefit you? Let us know!

Publisher's Statement

Copyright 2005 Cambridge University Press. Available on publisher's site at

http://journals.cambridge.org/abstract_S0020818305050320.

\section{Original Citation}

Lewis, Jeffrey. 2005. "The Janus Face of Brussels: Socialization and Everyday Decision Making in the European Union." International Organization 59:937-971.

\section{Repository Citation}

Lewis, Jeffrey, "The Janus Face of Brussels: Socialization and Everyday Decision Making in the European Union" (2005). Political Science Faculty Publications. 16.

https://engagedscholarship.csuohio.edu/clpolsci_facpub/16

This Article is brought to you for free and open access by the Political Science Department at EngagedScholarship@CSU. It has been accepted for inclusion in Political Science Faculty Publications by an authorized administrator of EngagedScholarship@CSU. For more information, please contact library.es@csuohio.edu. 


\title{
The Janus Face of Brussels: Socialization and Everyday Decision Making in the European Union
}

\author{
Jeffrey Lewis
}

\begin{abstract}
This article examines the European Union's Committee of Permanent Representatives, or COREPER, a group composed of the EU permanent representatives (permreps) and responsible for preparing upcoming ministerial meetings of the Council. As the heart of everyday decision making in the EU, COREPER is a key laboratory to test whether and how national officials become socialized into a Brusselsbased collective culture and what difference this makes for EU negotiations. The key scope conditions for COREPER socialization are high issue density/intensity and insulation from domestic politics. COREPER also displays a range of socialization mechanisms, including strategic calculation, role playing, and normative suasion. Based on extensive interview data and a detailed case study of negotiations for a controversial EU citizenship directive, this article documents a socialization pathway in COREPER marked by adherence to a set of norm-guided rules and principled beliefs in collectively legitimating arguments and making decisions. COREPER socialization does not indicate a pattern of national identities being replaced or subsumed; rather, the evidence points to a socialization process based on a "logic of appropriateness" and an expanded conception of the self.
\end{abstract}

Not many international institutional environments can match the density or robustness of collective decision-making norms found in the European Union (EU). ${ }^{1}$ But there are surprisingly few empirical studies of how these collective norms operate in the EU. There is an even greater shortfall of research on the effects of this institutional environment on the basic actor properties of the national officials who participate in this system. ${ }^{2}$ How does the culture of decision making in the EU affect agents and their bargaining behavior? This article focuses on the Com-

For feedback on earlier versions, I am grateful to the project participants and especially Jeffrey Checkel, Matthew Evangelista, Iain Johnston, and Michael Zürn. I thank the editors and two anonymous reviewers for comments that greatly improved the final product. I also acknowledge generous support from the Max Planck Institute for the Study of Societies and the American Political Science Association's Small Grant Program, which funded portions of field research associated with this project.

1. For a discussion of this point, see Kahler 1995, 82-89; and Wallace 1994, 41-50.

2. Recent exceptions include Trondal 2001 and 2002; Egeberg 2004 and 1999; Egeberg, Schaefer, and Trondal 2003; and Joerges and Vos 1999. 
mittee of Permanent Representatives (COREPER), a Brussels institution responsible for preparing upcoming ministerial meetings of the Council, and, as such, the heart of "everyday" EU decision making. ${ }^{3}$ The members of COREPER, known as the EU permanent representatives, are exemplars of "state agents" given their prominence in articulating, arguing, and defending national interests across the gamut of EU affairs. ${ }^{4}$ COREPER is thus a key laboratory to test whether and how state agents become socialized into a Brussels-based culture of EU decision making.

COREPER is the main preparatory body for the Council of the European Union, the legislative heart and unabashed defender of national interests in the EU. Composed of senior civil servants and career diplomats, COREPER members meet weekly and have evolved a style of decision making that is rooted in a collective culture with its own informal norms, rules, and discourse. ${ }^{5}$ Some permanent representatives even joke that this collective culture makes them unpopular with home ministries; for example, German Ambassador Dietrich von Kyaw claimed that back home he was known as the ständiger Verräter (permanent traitor) instead of the ständiger Vertreter (permanent representative). ${ }^{6}$

The central question of this article is whether and how the context and quality of interaction among national representatives in COREPER can have transformative effects on basic actor properties. Unlike traditional rationalist accounts, which begin from the premise that institutional environments primarily affect strategy, ${ }^{7}$ this article seeks to test constructivist claims that institutional environments can also affect cognition, attitudes, and identity. Rather than posing this as an "either/ or" question, to competitively test rationalism "versus" constructivism, this article asks whether the constructivist line of questioning can add value to baseline rationalist accounts. Based on an original data set of interviews with participants and case-study research of negotiation histories, this article documents how COREPER offers an unambiguous example of interstate negotiation in which state actors' range of motivations include a blend of appropriateness and consequentialist logics. ${ }^{8}$

3. Since 1962, COREPER has met weekly in two formats: COREPER II is composed of the EU ambassadors and works primarily on the monthly meetings of the foreign ministers in the General Affairs Council (GAC); COREPER I is made up of the EU Deputies, and they preside over a wide range of so-called "technical" Councils such as the Environment, Fisheries, Employment and Social Policy, and so on. Thus, strictly speaking, COREPER consists of fifty members (twenty-five ambassadors, and twenty-five deputies) who are jointly referred to as the EU permanent representatives. For the more subtle differences in prestige and clout between COREPER I and II, see Lewis 2002; and Hayes-Renshaw and Wallace 1997.

4. There are two substantive exceptions: the Agricultural Council (which is prepared by the Standing Committee on Agriculture [SCA]) and the Ecofin Council (prepared by the Economic and Finance Committee [EFC], which has its own vertical channels to the finance ministers, effectively bypassing COREPER).

5. See Lewis 2000; and Bostock 2002.

6. Dietrich von Kyaw was Germany's EU Ambassador from 1993-99. For a discussion of his Verräter quip, see Lionel Barber, "The Men Who Run Europe," The Financial Times, 11 March 1995, Sec. 2, I-II. See also Hayes-Renshaw and Wallace 1997, 224-25; and Wallace 1973, 56.

7. For examples, see Eising 2002, 87; and Bjurulf and Elgström 2004.

8. March and Olsen 1998. 
Following Checkel's definition of socialization as "a process of inducting actors into the norms and rules of a given community," 9 this article tracks how COREPER participants exhibit a range of behavior and collectively legitimate arguments on the basis of a "reasoned consensus" that the logic of consequences by itself cannot explain. The outcome of socialization is the internalization of group-community standards by the EU permanent representatives (permreps), reflected in bargaining behavior and decision outcomes. Successful socialization, then, is evidenced by what Checkel calls "sustained compliance based on the internalization of ... new norms and rules." ${ }^{10}$ Furthermore, fine-grained analysis of the EU local elections negotiations (as will be discussed in the fourth section) will allow more nuanced discrimination between Type I (role playing) and Type II (normative suasion) patterns of internalization. ${ }^{11}$

Joining the COREPER "club" involves more than behaviorial adaptation to institutional norms that alter incentives and strategies. EU permreps also internalize group-community standards that become part of an expanded conception of the self. This internalization includes a distinct epistemic value in the collective decisionmaking process itself. ${ }^{12}$ The standards of appropriateness found in COREPER include norms ruling out certain instrumental behavior (such as "pushing for a vote" under conditions of qualified majority voting), obligations to practice mutual responsiveness and collectively legitimate arguments (including appropriateness standards for dropping arguments that fail to convince the group), and a duty to "find solutions" and keep the legislative agenda of the Council moving forward. However, this collective culture does not trigger shifts of loyalty or transfers of allegiance. Instead, one sees a more complex layering of national and European frames. The interview data consistently show that EU permreps do not perceive sharp tradeoffs between national and European allegiances. When discussing their job descriptions, permreps frequently refer to having dual personalities, performing multiple roles, wearing different hats, even having a "Janus face." ${ }^{13}$ As former British Deputy Permanent Representative David Bostock explains:

Members of COREPER describe themselves as being bound by a "dual loyalty." It is their responsibility faithfully to represent their Member States; but it is also their responsibility to reach agreement. The Roman god Janus, facing in two directions, is thus COREPER's patron saint, mascot, or role model. ${ }^{14}$

Thus the identity configuration of EU permreps appears, even at first glance, more subtle and complex than zero-sum notions of loyalty and allegiance. In COREPER,

9. Checkel, this volume.

10. Ibid.

11. Ibid.

12. This is compatible with what Lax and Sebenius call the development of "process interests" or "intrinsic interests in the character of the negotiation process itself." Lax and Sebenius 1986, 72.

13. Author's interview, 20 February 1996. All interviews were conducted in Brussels unless noted otherwise.

14. Bostock 2002, 217. 
what one sees instead is the cognitive blurring of sharp definitional boundaries between the "national" and "European" frames, and a shared sense of responsibility to deliver both at home and collectively. As this article will show, the pattern of socialization found in COREPER does not lead to the creation of a new overarching supranational identity, but rather to a more complex configuration of identity than is typically acknowledged.

The remainder of this article is organized as follows. The next section provides a concise summary of the theoretical argument. The second section details the pathway of socialization found in COREPER, with an emphasis on the scope conditions and mechanisms at work. The necessary scope conditions are high issue density/intensity and insulation from domestic politics, both of which imply that the socialization process in COREPER is forged by the "quality" of the link. The mechanisms explaining how socialization occurs in this institutional environment include strategic calculation, role playing, and normative suasion. Following this, the third section discusses methods and the strategy of empirical triangulation. Section four contains the empirical story, which traces the negotiations of a controversial EU citizenship directive that was quietly resolved by COREPER and sent to the ministers for formal adoption. Specifically, the case covers the 1994 local elections directive granting all EU citizens the right to vote and run for office in the local elections of their current residence (that is, granting nonnational EU citizens local voting and participation rights). Finally, a brief concluding section summarizes how the identity configuration of permreps muddies conventional distinctions between "national" and "supranational" agency.

\section{Overview of the Theoretical Argument}

For rationalists, identities and interests are taken as preset and given, and the empirical focus is on the role of formal decision rules, relative power, and instrumental rationality in explaining bargaining outcomes. ${ }^{15}$ State agents are motivated more by a "logic of anticipated consequences and prior preferences" 16 than by notions of responsibility, obligation, or informal, "soft law" rules and norms. In the rationalists' strategic conception of rules, actors employ language and communication as rhetorical devices to pursue instrumental interests, manipulate incentive structures via social influence, and so on. ${ }^{17}$ Normative compliance is the result of crafted, calculative reasoning and expected future benefits. While institutional environments have constraining and enabling effects on behavior by altering incentives, the impact of institutions on basic actor properties (attitudes, identities) is considered epiphenomenal.

Constructivism relaxes the assumption of preset, given interests and identities, allowing for the possibility that institutional environments may have transforma-

17. See Schimmelfennig 2000; and Schimmelfennig, this volume. 
tive effects on basic actor properties. Relative power brokering and instrumental rationality are accorded less primacy than in rationalism, and supplemented with attention to the deliberative aspects of negotiation, such as the role of discourse, persuasion, and the collective legitimation of arguments. According to the constructivist approach, EU institutions are hypothesized to have "thick" socializing effects on actors, which go beyond instrumental adaptation and strategic calculation to include the internalization of norms and rules into self-conceptions. In other words, the densities of institutional and normative environments are considered causal variables that, under the right background conditions, can have transformative effects on basic actor properties, including how individuals see themselves (conceptions of the self) and how they conceptualize their interests. In the case of successful socialization, then, the constructivist expects to see interests that "have been conditioned by a community standard that delimits the acceptable." 18 As the case evidence will show, one can further distinguish the internalized norms argument into Type I cases, where agents follow "socially expected behavior in a given setting or community," and Type II cases of accepting community norms as "the right thing to do." 19

The socialization story documented here does not disprove or contradict a rationalist reading, ${ }^{20}$ but at the same time there is abundant support for a "soft" constructivist account that brings the collective culture and normative environment of Brussels-based decision making into the picture. Essentially, what one sees in the institutional environment of COREPER among the EU permreps is an expanded conception of the self that includes noninstrumental, pro-norm behavior without the threat of external sanctioning; it is based on the internalization of standards of appropriateness. This can be consistent with rationalism, but it is necessary to expand the baseline of "self-interest" beyond utility maximization to include a wider range of egoistic and other-regarding perspectives. As such, this study joins a growing number of researchers who see value in developing more nuanced models of rationality beyond the instrumental understanding embedded in nearly all forms of rational choice. ${ }^{21}$

\section{Alternative Explanations: Internalized Norms or Diplomacy 101?}

The alternative explanation for everyday EU decision making is standard negotiation theory and two-level games analysis. ${ }^{22}$ The falsification test for the social-

18. Hurd 1999, 397.

19. Checkel, this volume.

20. See Zürn and Checkel, for a thoughtful "double interpretation."

21. For a discussion of different "models of theoretical dialogue" between rationalism and constructivism, including the tricky issues of "paradigmatic privileging" and "first mover" advantages, see Jupille et al. 2003, 19-28.

22. The literature on negotiation theory is voluminous. Classic works include Lax and Sebenius 1986; Raiffa 1982; Iklé 1964; Rapoport 1960; Pruitt 1981; Strauss 1978; Zartman and Berman 1982; and Walton and McKersie 1965. See also Jones 1994; Kramer and Messick 1995; and Rubin and Sander 1988. On two-level games, see Putnam 1988; and Evans 1993. 
ization story presented here is essentially: how does this differ from "diplomacy 101"? Using standard negotiation analysis, one would not be surprised to find, among the EU permreps, regularized practices of mutual understanding, moderating demands, and generalized reciprocity, especially given the scope conditions discussed in the next section. But according to this model, the motivations and incentive structures of the permreps would be firmly rooted in the consequentialist logic of an instrumental conception of the self and attendant interests. Against this default argument, I ask whether the empirical record shows an institutional context in which not just a logic of consequences is in play, but a distinct logic of appropriateness as well. Can one find evidence of an expanded conception of the self among national officials, and how would this differ from "normal" unsocialized bargaining in mixed-motive games?

To illustrate such differences, one can hypothesize four measures that would support the appropriateness logic and cut against the grain of conventional bargaining and two-level games analysis wedded to a logic of consequences.

1. Noninstrumental self-restraint in demands and arguments. Unlike the instrumental cost-benefit logic implicit in negotiation theory, self-restraint is now motivated by a sense of responsibility or obligation (especially to protect what Lax and Sebenius call "process" and "relationship" interests). ${ }^{23}$ Consistent with standard negotiation theory would be evidence of EU officials with an altered "feasibility calculus" ${ }^{24}$ for determining what strategies work, including when and how to make demands and to avoid being a demandeur too often. However, self-restraint as it is used here involves a noncalculative, noninstrumental rationale. Examples of self-restraint would include delegations who drop demands or reservations after failing to convince the group of an argument. Most relevant for the alternative-explanation test is whether one finds instances of self-restraint that do not follow from calculative reasoning (for example, "Do I have the votes?") or, especially, self-restraint where the option of veto or threat thereof exists. To the extent that one finds evidence supporting acts of self-restraint under such conditions, this would lend support to the internalized norms argument.

2. Self-enforcing adherence to informal decision-making norms without threats of external sanctioning. If standard negotiation theories were on the mark, one would expect to see a utilitarian conception of rule-following behavior, supplemented by evidence of regularized cost-benefit analysis. The reason, as Hurd explains, is because "any loyalty by actors toward the system or its rules is contingent on the system providing a positive stream of benefits ...

23. See fn. 12 for their definition of "process" interests. "Relationship" interests are those in which negotiators "stress the value of their relationships," which can sometimes (under iterative bargaining) take on "an almost transcendent status." Lax and Sebenius 1986, 72.

24. Kerremans 1996, 232. 
actors do not value the relation itself, only the benefits accruing from it." 25 If the instrumental conception of rules fit here, one would also expect to see reliance on institutional enforcement mechanisms and formal rules governing acceptable bargaining behavior. ${ }^{26}$ In contrast, "sustained compliance" 27 with informal norms in the absence of external sanctions and calculative reasoning would support the argument that state agents negotiate from shared understandings of appropriate community standards. ${ }^{28}$

COREPER norms are informal and self-enforcing ${ }^{29}$ because adherence to them is considered the "right thing to do," as part of the permreps' principled commitment to collective decision making. ${ }^{30}$ The reflex to make decisions by consensus is a classic example of this and a durable practice vicwed by the EU permreps as the "right thing to do" regardless of the formal decision-rule. One ambassador claimed that the "consensus-seeking assumption ... penetrates, in my mind, everything we do." 31 The mode of social control in COREPER is compatible with Hurd's legitimacy model, in which it is "noncompliance that requires of the individual special consideration and psychic costs," and in which "the internalization of external standards can ... defuse Olsonian problems of collective action by causing actors to interpret the mutually cooperative option as also being the individually rational one." 32 Or as Wendt puts it, "external constraints become internal constraints, so that social control is achieved primarily through self-control." 33 Evidence of self-enforced informal norms without the threat of external sanctions and constraints would support the noninstrumental appropriateness logic.

\section{Empathy and other-regarding behavior not linked to calculative reasoning.} The alternative explanation would expect to find empathic behavior linked

25. Hurd 1999, 387.

26. For example, one would expect to see wide recourse to formal rules such as the 1994 Ioannina Compromise, which holds that under conditions of qualified majority voting when a clear blocking minority does not exist (but at least twenty-three to twenty-five votes oppose), the Council will still "do all within its power" to find a "satisfactory solution." Dinan argues that the Ioannina Compromise was a "face-saving device" for "anti-EU" back-benchers in the British parliament and has "had no practical impact on EU decisionmaking." Dinan 1998, 299. For a similar argument-that the impact of the infamous 1966 Luxembourg Compromise to protect "vital national interests" has been highly exaggerated and largely unimportant for bargaining outcomes—see Golub 1999.

27. See Checkel, this volume.

28. Although it should be added here that evidence of this measure may be compatible with either Type I or Type II internalization. Additional tests are needed to measure the degree of "taken-forgrantedness." A useful index to operationalize the distinction used here is the discussion in Hurd 1999 of "habitual" versus "holistic" internalization.

29. See the "Socialization Mechanisms" section below.

30. See also Gheciu, this volume, in which she codes successful socialization as cases where norms are accepted because they are considered normal and "the right thing to do" is to comply with them; norms are not accepted just because they are directly linked to instrumental rewards.

31. Author's interview, 18 March 1997.

32. Hurd 1999, 388-89.

33. Wendt $1999,361$. 
to instrumental calculations, and in an issue-intensive, in-camera setting such as COREPER, this would be based on both longer time horizons (for example, "I may need help next week") and reputational concerns. But the internalized norms argument expects to see acts of empathy and other-regarding behavior based on a different kind of calculus. The difference from the consequentialist logic is that the internalized norms model expects such acts to be what Wendt calls "self-binding" or "unilateral initiatives with no expectation of specific reciprocity." ${ }^{34}$ Evidence supporting the internalized norms argument would include examples of empathy not linked to an instrumentalist conception of interests but seen as "the right thing to do."

More specifically, evidence for Type II—internalized norms-socialization would include those cases in which national representatives worked to convince superiors back in the capitals to accept another delegation's plea or argument while dropping their own, even when veto options existed. This practice would be coded as normative suasion because actors who are persuaded by another's argument then defend the position to their authorities, seeking to convince those authorities to accept the reasoning while at the same time dropping their own unconvincing claim. In other words, these actors are successfully persuaded to change positions, and this carries potential costs to implement (that is, they risk the ire of the capital). Especially relevant for the collective community standards argument are those cases in which the group actively "plots" solutions to overcome domestic reserves, sometimes faking group outrage or artificially simulating a delegation's isolation on a position. ${ }^{35}$

But the empathy indicator is also clearly a case in which it is misleading to frame the question as "rationalism versus constructivism," as both schools offer similar predictions. Indeed, Keohane discusses several different ways that states can interpret self-interests "empathetically," some of which are consistent with standard bargaining (this would include other-regarding behavior he terms "instrumentally interdependent" and "situationally interdependent") and some of which are more akin to the internalized norm conception (for example, what he calls "empathetic interdependence"). ${ }^{36}$

4. Limits on instrumentalism through the collective legitimation of arguments. Such acts would be especially relevant-and contrary to standard negotiation predictions-where delegations drop demands after failing to convince the group, despite a theoretical recourse to the threat or use of veto under the unanimity decision-rule. Evidence that standards of appropriateness exist can be seen in cases where group outrage is used to signal that certain things are just not acceptable. One can further contextualize the internalized norms argument into Type I cases in which agents follow "socially expected behavior

34. Wendt 1999, 362.

35. For a discussion of "plotting" practices in COREPER, see the "Mechanisms" section below.

36. Keohane 1984, 120-25. 
in a given setting or community" and Type II cases of accepting community norms as "the right thing to do," ${ }^{37}$ a point returned to in the fourth section, below. But in general, both variants deviate from the alternative explanation of standard negotiation by their noninstrumental, noncalculative motivations.

\section{The Pathway of Socialization in COREPER}

COREPER is "responsible for preparing the work of the Council and for carrying out the tasks assigned to it by the Council." ${ }^{38}$ From this austere legal basis, COREPER has evolved into a major player in the EU system. Among its "assigned tasks" is the remit to "coordinate the work of the various Council meetings and to endeavour to reach agreement at its level." ${ }^{39}$ In essence, this means that COREPER holds responsibility for the performance of the Council as a whole. Permreps claim that this responsibility is an implicit part of the job description. As one ambassador put it, "there is a high collective interest in getting results and reaching solutions. This is in addition to representing the national interest." ${ }^{40}$ Another claimed to have an unwritten, global, permanent instruction to "find solutions." ${ }^{41}$ Whatever the case and as these quotes suggest, logics of appropriate behavior and socialization dynamics seem evident within COREPER. The analytic challenge is to establish their scope conditions and mechanisms of operation, tasks to which I now turn.

\section{Scope Conditions}

Issue density/intensity. COREPER's structural placement imparts a coherence and continuity in the representation of interests that would otherwise be difficult to match. In terms of structural location, COREPER occupies a unique institutional vantage point in the EU system. Vertically placed between the experts and the ministers and horizontally situated with cross-sectoral policy responsibilities, the permreps have a general overview of the Council's work. Relative to the experts meeting in the working groups, they are political heavyweights; but compared to the ministers, they are both policy generalists and experts in the substantive questions of a file.

Since the Council's work is based on a concept of sectoral differentiation, pursuing the "national interest" across its sixteen or so formations requires national systems of interest intermediation and interministerial coordination that are complex even for the smallest member states or those with the most centralized EU

37. Checkel, this volume.

38. Art. 207, Treaty on European Union.

39. Council of the European Union 1997, 39.

40. Author's interview, 12 July 1996.

41. Author's interview, 20 February 1996. 
affairs machinery. It is here that the permreps in COREPER, with their crossCouncil negotiating mandates and intersectoral policy responsibilities, practice an essential aggregation function. A central feature of COREPER's institutional environment is the density of issues and issue-areas that are covered in the agendas of the weekly meetings. No other site of everyday EU decision making approximates the intensity of weekly COREPER negotiations (measured in terms of the number of weekly agenda items and the horizontal nature of these agendas). Thus the agendas of COREPER meetings are qualitatively different than the type encountered at the Council working group level. Unlike the "contact thesis" then, which equates socialization with the amount of interaction, ${ }^{42}$ the pattern discerned here is contingent on the density and quality of interactions.

Not only is COREPER distinguished by the intensity of negotiations, but the permreps' involvement across the different domains of EU decision making is pervasive as well. In addition to the regular cycle of weekly meetings, the permreps sit beside their ministers during Council sessions, briefing them and offering tactical suggestions. Permreps attend European Council summits and can serve as behind-the-scenes consultants. The growth of codecision (now considered the EU's "ordinary" legislative procedure) has also created an intense negotiation forum between members of the European Parliament (MEPs) and the deputy permreps who represent the Council. ${ }^{43}$

Reinforcing the intensity of interactions, the EU permreps also accumulate a great deal of experience through long periods of participation. ${ }^{44}$ The average tenure is five years, slightly longer than the typical three- or four-year diplomatic rotation. ${ }^{45}$ But some permreps remain in Brussels for much longer, upwards of a decade or beyond. Another reinforcement mechanism is the COREPER luncheon, held by COREPER II before the monthly General Affairs Council (GAC) and sometimes on a more topical, ad hoc basis. Lunches are frequently used to tackle the thorniest of problems, since attendance is heavily restricted, no notes are taken, and not even translators are present. ${ }^{46}$ There are also informal COREPER trips, hosted by the presidency, that precede European Council summits.

In sum, the first scope condition is COREPER's unique structural position in everyday EU decision making, with a brand of intensity that is generated by the density and scope of agendas and widespread participation in nearly all aspects of the Council's work; this is reinforced by extensive periods of interaction and numerous informal venues for negotiation. This scope condition can also be restated in hypothesis form:

42. See Checkel, this volume.

43. Bostock 2002.

44. See Checkel, this volume, for a discussion of the methodological problems in conflating the intensity and duration of interaction.

45. Lewis 1998, 111-13.

46. Butler 1986, 30. 
H1: The internalization of new role conceptions and conceptions of the self in line with group-community norms is more likely when individuals are in settings where contact is intense and sustained.

Insulation. One of the central features of COREPER diplomacy is a high degree of insulation from the normal currents of domestic constituent pressures. The meetings themselves are treated with an air of confidentiality, and many sensitive national positions are ironed out in restricted sessions in which the permreps clear the room and can speak frankly and in confidence that what is said will not be reported to the capitals or the media. This often includes group discussion on how an agreement will be packaged and sold to the authorities back home. "At our level, publicity does not exist," an ambassador explained, "Our body is absolutely black; we can do deals." ${ }^{47}$ The norms of insulation are so developed that national experts from the capitals are not allowed to attend COREPER meetings at all (one official referred to them as "spies," another called them "the watchdogs" who "are not allowed in the room"). ${ }^{48}$ The role of insulation in COREPER diplomacy supports Checkel's hypothesis ${ }^{49}$ that persuasion and socialization are more likely in "less politicized and more insulated, in-camera settings."

A structural feature of COREPER that often goes unnoticed is that insulation affords member states the capacity to reshape domestic constraints. As an ambassador put it, "COREPER is the only forum in the EU where representatives don't have a domestic turf to defend." Because of this, he went on to add, "it is often politically necessary to present a position knowing it is unrealistic. My minister of finance needs certain arguments to be presented. He has certain pressures from his constituencies. We have to make it look like we fought for this even though we both know it will lead nowhere. I will present it, and if it receives no support, I will drop it." 50 Along with insulation comes a high degree of input ("voice") in the instruction process, including how arguments/interests are articulated and defended. The degree of voice that the permreps can obtain stems from COREPER's basic mission to find solutions and keep the work of the Council moving forward. One intriguing argument as to why states would choose to create such a highly insulated body comes from recent work by Stasavage. Using a rational choice framework, he shows how "open-door bargaining" and greater levels of transparency can increase "posturing" by negotiators, since they have built-in incentives to present unyielding positions "in order to demonstrate to their constituents that they are effective or committed bargainers." 51

47. Author's interview, 23 May 2000.

48. Author's interviews, 23 May 2000; and 18 April 1997.

49. See Checkel, this volume.

50. Author's interview, 15 May 2000.

51. Stasavage 2004, 673. 
Domestic insulation has enabled the permreps to develop de facto decisionmaking capabilities. ${ }^{52}$ The best empirical indicator of the weight of COREPER's decision-making role is the prolific "A-point" procedure. A-points are "agreed points" (that is, issues agreed to within COREPER) that are passed en bloc and without discussion by the ministers at the beginning of each Council session. ${ }^{53}$ Even for files marked as B-points (that is, issues sent to the ministers that require further discussion), the input of COREPER should not be ruled out. In many cases, detailed negotiations have already taken place in COREPER (see the case study below for an example). It is remarkable, in fact, that COREPER's burgeoning de facto decision-making power has escaped every post-Maastricht "democratic deficit" revision unscathed, entirely on the rather thin reed that only ministers have juridical decisional authority.

To summarize, the second scope condition for COREPER socialization is insulated-from both domestic constituencies and domestic line ministriesnegotiation, coupled with de facto (as opposed to juridical) decision-making authority. This can be restated as follows:

H2: The internalization of new role conceptions and conceptions of the self in line with group-community norms is more likely when individuals are in private, incamera settings with a high degree of domestic insulation.

Having identified the key conditions under which to expect socialization, I turn now to the major factors that explain how this process occurs and how it can lead to shared understandings of appropriateness-understandings that produce behaviors different from those based on instrumental and utilitarian calculations alone. ${ }^{54}$

\section{Socialization Mechanisms}

Strategic Calculation and Role Playing: Adherence to Informal Norms. A distinctive feature of COREPER's institutional environment is a robust set of durable yet unwritten and purely informal decision-making norms. One of the most striking aspects of these informal norms is their seemingly "self-binding" nature (Wendt's term). Why do national representatives comply? The interview data strongly suggests that COREPER participants practice pro-norm behavior (in the absence of external sanctioning) because it leads to the acquisition of social influence and diffuse, intangible "social capital." ${ }^{55}$ As a mechanism of socialization,

52. The permanent representatives have no formal decision-making authority. Juridical decisionmaking authority is a power exclusively reserved for the ministers, and formal voting is expressly prohibited at any other level of the Council (compare Art. 7[1] of the Council's Rules of Procedure).

53. Recent studies of the Council have documented the growth and importance of the A-point procedure in the EU legislative process. See, for example, van Schendelen 1996; and Gomez and Peterson 2001.

54. I thank an anonymous reviewer for suggesting this language.

55. For a discussion of "social capital," see Putnam 1993, 169-70. 
behaviorial adaptation to acquire social influence is what this volume would code as strategic calculation. ${ }^{56}$

The explanation does not end there, however. To get what you want in COREPER, you must also subscribe to socially accepted standards of behavior. Evidence of this pattern would support what this volume calls Type I internalization or role-playing socialization. These informal norms act as cognitive markers for newcomers to adapt to the group's accepted standards. As I will show below in the case of Austria's "opt-out" argument, the group can reject arguments with exaggerated ferocity to shame capitals and pressure a change in national demands. Group outrage is used to signal that certain behavior and justification for demands is simply not done or is not acceptable.

Five informal norms stand out. First, there is a norm of diffuse reciprocity, or the diffuse balancing of concessions over an extended shadow of the future. ${ }^{57}$ Diffuse reciprocity can take many forms, including concessions and derogations, or "going out on a limb" to persuade the capital for changes or a compromise. Dropping reserves or abstaining (rather than voting "no") are also political gestures that can be filed away and later returned in kind.

Second, there is a norm of thick trust and the ability to speak frankly, which is reinforced by weekly meetings, trips, and lunches. Thick trust is especially important during endgame negotiations or restricted sessions when the "real knives come out on the table." 58 Third, there is a norm of mutual responsiveness that is best described as a shared purpose to understand each other's problems. Knowing and understanding each other's interests and arguments is a key to "receiving understanding from the group." ${ }^{59}$ Mutual responsiveness is a form of collective legitimation, wherein arguments or pleas for special consideration are collectively accepted or rejected by the group. The fourth norm is a consensus-reflex. This is what Hayes-Renshaw and Wallace refer to as "the instinctive recourse to behave consensually." ${ }^{60}$ Although systematic empirical data is lacking because of the confidentiality of negotiations, participants claim that the overwhelming bulk of decisions are made consensually. Even under conditions of qualified majority voting (QMV), permreps often spend extra time to "bring everyone on board." Pushing for a vote is considered inappropriate in most cases, and the "consensus assumption" is a reflexive habit. ${ }^{61}$

Finally, there is a culture of compromise premised on a basic willingness to accommodate divergent interests and reinforced by the other norms listed above. This culture is facilitated by the "dynamic density" of COREPER's work and the

56. See Checkel, this volume.

57. See Keohane 1986 for the classic treatise on "diffuse reciprocity."

58. Author's interview, 14 March 1996. On the concept of thick trust, see Putnam 1993, 167-71.

59. Author's interview, 17 February 1997.

60. Hayes-Renshaw and Wallace 1995, 465.

61. Author's interview, 18 March 1997. 
horizontal nature of agendas. The normative effects of this culture include a selfrestraint in the calculations and defense of interests, seen for example when delegations quietly drop reserves after failing to convince the others of their arguments.

Taken together, these informal norms are widely practiced and firmly institutionalized in COREPER's organizational culture. ${ }^{62}$ As the case study of local elections negotiations will show, adherence to these norms cannot be explained by either a pure incentive-based (consequentialist) or normative (appropriateness) logic, but instead represents a subtle blending of the two. That is, pro-norm behavior is rooted in a complex combination of both strategic calculation and role-playing socialization. Which came first, and how these normative scripts became institutionalized into COREPER routines, remains largely to be told.

Normative suasion. COREPER has its own locution, with signals, key phrases, and unspoken meaning. There is also a certain element of theatricality, in manufacturing intrigue; how else could one sit through yet another round of fishing quotas, as one permrep alluded. All of this is the typical grammar of diplomats, to be expected in issue-intensive, insulated settings where negotiators develop long-term interpersonal relationships. Going further though, one also sees a wide range of discursive resources that permreps can use in presenting and collectively legitimating arguments. This real possibility for normative suasion is what separates COREPER from the alternative argument of "normal" interstate negotiation. For example, as the local election case study will show, COREPER is considered the EU's locus classicus for "opt-out" negotiations, since permreps use collective legitimation to determine who warrants special consideration backed by standards of fairness where persuasive justifications carry the day (rather than relative power, voting weights, or the decision-rule). Evidence of this pattern would tend to support Checkel's hypothesis ${ }^{63}$ that socialization is more likely where agents do not "lecture or demand" but rather act on "principles of serious deliberative argument."

Learning the derogation discourse is an important tool of the trade in COREPER, and senior permreps develop idiosyncratic methods for signaling when they need special dispensations. For many, this includes having a sense of humor when isolated or when national political sensitivities are being discussed. Normative suasion is an important socialization mechanism in COREPER, and unlike the mechanism of strategic calculation, it is sustained over time without respect to the structure of incentives or the existence of external sanctions. But argumentative resources are intertwined by consequentialist and appropriateness logics, and it is often difficult to tease the two motivations apart.

Put differently, in COREPER, arguments matter. While a truism in almost any type of negotiation, there are no comparable sites within the Council where the 
persuasive power of one's arguments weighs on outcomes. ${ }^{64}$ Representatives claim that they come prepared to convince and be convinced by others, and many of the weekly meetings are geared toward reaching a "reasoned consensus" rather than a vote. ${ }^{65}$ Arguing and persuasion are also seen in how the permreps signal that something is particularly important or request mutual understanding from the group (irrespective of the formal decision-rule).

Participants claim that even in rare instances when they do vote, it is exceptional that this is done without the consent of the "no's." ${ }^{66}$ In COREPER, the power of a good argument can be as compelling as a blocking minority or the shadow of the veto. The possibility of persuading others with a convincing argument and the norms of mutual responsiveness work as a great equalizer in COREPER negotiations. As a result, smaller member states who articulate sound arguments and/or clearly explain their positions can often punch above their weight. According to one participant, "If you convince others, it's with good arguments. Big or small makes no difference. In fact, the big member states often have higher burdens of proof in order to convince the others." 67

Another example of normative suasion is how permreps engage in the collective "plotting" of agreements. ${ }^{68}$ Plotting is a negotiation pattern in COREPER that demonstrates how a collective rationality can reformulate individual, instrumental rationality. The basic function of plotting is using the group to redefine a national position or to reshape domestic constraints. "69 "To get new instructions we have to show [the capital] we have a black eye," an ambassador explained, "We can ask COREPER for help with this; it is one of our standard practices." ${ }^{70}$ According to another, "Sometimes I will deal with impossible instructions by saying, 'Mr. Chairman, can I report back the fierce opposition to this by the fourteen others?' And sometimes fierceness is exaggerated for effect." ${ }^{71}$ Exaggerating the fierceness of opposition is thus a group strategy to collectively legitimate or reject arguments. A clear illustration of this practice is seen below in the way the group handles Austria's claim for special treatment.

In general, as standard negotiation theory explains, plotting and underlining opposition are tools of the trade to deal with recalcitrant bargaining positions. But in

64. But see Puetter's 2003 analysis of the Eurogroup Council as a deliberative process based on a "shared normative framework."

65. Although it is important to emphasize here that EU permreps, without exception, stress the importance of the decision-rule in contextualizing negotiations. It is a cliché in COREPER that qualified majority voting is the surest way to reach consensus.

66. Author's interviews, 15 May 2000; and 12 July 1996.

67. Author's interview, 29 May 2000. Based on survey data of 218 national officials in the EU, Egeberg, Schaefer, and Trondal find that influence on committees is considerably higher among those with demonstrable expertise than those from big states per se. Egeberg, Schaefer, and Trondal 2003, 28, tab. 11 .

68. See Lewis 2002, 292, for an example.

69. Two-level games researchers call this "COG collusion.” Evans 1993, 406-7.

70. Author's interview, 15 May 2000.

71. Author's interview, 26 May 2000. 
COREPER, this takes on an additional layer of collective legitimation as a framework of shared meaning within the standards of appropriateness. As Risse argues, in a "collective communicative process" actors are engaged in determining "whether norms of appropriate behavior can be justified, and which norms apply under given circumstances." 72 This is a hallmark of COREPER's role in the EU system, and viewed from the process level of everyday decision making, the stamp of collectively negotiated standards of appropriateness is unmistakable. In the case of local elections (see below), this can be seen in how the permreps deliberate derogation requests against a principled commitment for maximal interpretation of "equal treatment" standards in EU voting rights.

\section{Methods and Data}

My research design follows a methodological strategy of "empirical triangulation" combining several qualitative and quantitative data sources: semi-structured interviews, archival documentation (Council documents such as the travaux preparatoires, press releases, agendas, and so on), and secondary sources. My primary data sources are semi-structured interviews with COREPER participants. To date, I have conducted 118 interviews at the permanent representations and with regular COREPER participants from the Commission and the Council General Secretariat (CGS). ${ }^{73}$ Interviewing took place in four rounds over a seven-year period. ${ }^{74}$

\section{Controlling for Prior Exposure and Self-Selection}

Three methods were used to limit potential measurement problems, such as prior exposure to EU decision making. First, interview subjects were asked direct questions about their initial participation in COREPER negotiations, how they articulated their written instructions, and what, if any, changes occurred over time. Second, the interviews sampled "newcomers" at two levels: individual participants and new member states (both Nordic and Central/Eastern European newcomers are included in the sample). Third, I was able to re-interview some participants at a later date and compare their responses.

Several generalizable patterns emerged. The interviews track similar learning curves for newcomers, even those with different backgrounds and from different national administrative cultures. Participants typically claim that when they began attending the Committee, they learned that defending instructions alone had lim-

72. Risse $2000,7$.

73. The sample includes: thirty-one permanent representatives (eighteen ambassadors and thirteen deputies), thirty-two top advisors to the permreps (known as the "Antici" [COREPER II] and "Mertens" [COREPER I] counselors), thirty policy specialists, nine legal advisors, ten officials in national capitals, and six others.

74. Specifically, February-July 1996, February-April 1997, May 2000, and May-June 2003. 
ited effectiveness. ${ }^{75}$ This involves more than learning just strategy; effectiveness, according to participants, includes developing a sense of self-restraint and the ability to balance the specific instructions on a single file with more global instructions to keep the work of the Council moving forward.

Another pattern is that newcomers initially tend to view their counterparts as rivals. "I saw my colleagues as opponents at first," one deputy commented. ${ }^{76}$ Another claimed, "Early in our membership we acted tough and we had these positions, 'Others don't like it, too bad.' But the politicians back home learned fast to be prepared to compromise. Now we are known as a country others can turn to for a compromise." 77 On balance, the evidence suggests that newcomers have relatively high levels of ingrained cognitive priors, which supports Checkel's hypothesis $^{78}$ that under such conditions there will be greater resistance to normative suasion. The COREPER novice who "treats colleagues as opponents" undergoes a period of social learning (and mimicry) during which they adopt new cognitive templates in order to operate in an unfamiliar environment. Some newcomers recall receiving extra patience and understanding from the group; a permrep from one of the newer EU member states commented, "They [COREPER] gave [us] and the new member states special patience, but now I think that's over." 79

In summary, while no guarantee against potential measurement bias, the built-in controls of triangulation, newcomer sampling, and re-interviewing help to minimize such effects. More importantly, they strengthen the case for the independent causal influence of socialization dynamics within COREPER. To directly test the four socialization measures spelled out in section two, the argument now shifts to an examination of the 1994 local elections directive, a controversial and politically unpopular extension of voting and participatory rights for EU citizens. With this directive, for the first time, the EU allowed citizens from any member state to vote and run for office in municipal elections based on wherever they resided in the EU. ${ }^{80}$

\section{Socialization in COREPER: The Case of the 1994 Local Elections Directive}

The EU foreign affairs ministers, meeting in the GAC, adopted a directive on the right to vote and run for municipal elections on 19 December $1994 .{ }^{81}$ The

75. One common response was that following written instructions alone (that is, just reading from them) was a sure way to be left out of the discussion.

76. Author's interview, 17 March 1996.

77. Author's interview, 14 March 1996.

78. See Checkel, this volume.

79. Author's interview, 14 March 1996.

80. Numerically, the directive enfranchised approximately 5.3 million EU citizens living in another EU-15 member state. Lewis 1998, tab. 5-2, 215.

81. Council Directive 94/80/EC. The full title is the directive "[L]aying down detailed arrangements for the exercise of the right to vote and to stand as a candidate in municipal elections by citizens of the Union residing in a Member State of which they are not nationals." Official Journal L 368/38, 31 December 1994. 
substance of this directive had already been agreed upon twelve days earlier in COREPER. Negotiations were intentionally kept out of the GAC and the ambassadors were encouraged to reach an agreement in COREPER that could then be formally rubber-stamped by the ministers.

The local elections directive covered sensitive domestic political issues of electoral and citizenship laws, requiring the majority of member states to pass constitutional amendments to extend rights to "nonnational" EU citizens. The directive effectively established a principle of equal treatment between national and nonnational EU citizens. Moreover, the principle of equal treatment was agreed upon at a level of maximum coverage, with a minimalist interpretation of acceptable national "opt-outs." The principle of equal treatment agreed to in COREPER even went beyond earlier Commission proposals that considered minimum residency requirements a prerequisite for expanding local voting rights to Community nationals. ${ }^{82}$

During negotiations, several delegations (including Denmark, France, the Netherlands, and Sweden) initially voiced preferences for maintaining residency requirements that already existed in national law (see Table 1). However, the final terms of the directive allowed minimum residency rules in Luxembourg and, on an extremely limited basis, in Belgium. It was a shared understanding among the EU permreps that "opt-outs" would have to meet high standards for justification because of the potential for derogations to water down the scope and application of local voting rights. From the earliest discussions in COREPER, there was an informal and sometimes shifting majority of members who defended the need for equal treatment between national and nonnational EU citizens. Counterfactually, the argument presented here is that minus socialization, the final outcome would have been very different-if agreement would have been reached at all.

\section{Explaining the Local Elections Negotiations: Testing the Alternative Explanation}

This article contends that everyday EU decision making is not all about relative power, formal decision-rules, and instrumental interest calculations. If it were, the alternative argument is that bargaining behavior and everyday outcomes can be explained with standard negotiation theory and two-level games analysis. However, if the alternative explanation was correct, one would expect to see a very different sequence of bargaining behavior leading to a different kind of outcome than what occurred in this case. First, although at least four delegations (Denmark, France, Greece, and Austria) were interested in derogations and could have credibly linked such claims to the "shadow of the veto", none did. Moreover, after

82. The Commission's position was for minimum residence at least equal to the term of local office to vote, and double the term of office in order to stand for election. European Communities Bulletin 9-1986, 44. In effect, this would apply the Luxembourg derogation (see discussion below) to the entire EU. 
TABLE 1. National legislation governing municipal elections

\author{
Member state $\quad$ Basis for electoral rights $\quad \begin{gathered}\text { national legislation before the } 1994 \\ \text { local elections directive }\end{gathered}$
}

Ireland Residence

All nonnational residents eighteen years and older, who have lived in Ireland for at least six months can vote and run for office in local elections (1973 Electoral Act, right to vote; 1974 Electoral Act, right to run for office).

\section{Denmark Residence}

Netherlands Residence

Britain

Residence and nationality

Spain Nationality

Portugal Nationality

Finland Nationality

Sweden Nationality

France Nationality
Since 1977, the right to vote and run for local office has been extended to nationals of the Nordic Union (Finland, Sweden, Iceland, Norway) who are eighteen years or older and have met minimum residency requirements (Law of 18 May 1977).

In 1981, these rights were extended to all nonnationals (Law No. 143 of 30 March 1981 Amending the Law Governing Municipal Elections and by Decree of the Minister of the Interior No. 196 of 22 April 1981).

In 1983, Article 130 of the Constitution was amended to allow all nonnationals the right to vote and run for office in local elections, subject to a minimum residency requirements.

The right to vote and run for office in local elections is extended to Irish nationals and Commonwealth citizens who are over the age of eighteen (to vote) or twenty-one (to stand as candidate) and have met minimum residency requirements.

Since 1985, the right to vote in local elections (but not to stand as a candidate) can be extended to nonnational residents by treaty or law on a reciprocal basis (Article 3 of the General Electoral Law of 19 July 1985).

Since 1982, nationals of a Portuguese-speaking country may be given the right to vote in local elections by treaty or by law on a reciprocal basis. Only one such agreement was reached, with Brazil, extending the right for Brazilian nationals to vote in local Portuguese elections after having lived in Portugal for five years.

Since 1977, the right to vote and run for local office has been extended to nationals of the Nordic Union (Denmark, Sweden, Iceland, Norway) who are eighteen years or older, and have met minimum residency requirements.

Since 1977 , the right to vote and run for local office has been extended to nationals of the Nordic Union (Finland, Denmark, Iceland, Norway) who are eighteen years or older, and have met minimum residency requirements.

The rights to vote and run for office are constitutionally reserved for French nationals (Article 3). 
TABLE 1. (CONTINUED)

\begin{tabular}{|c|c|c|}
\hline Member state & Basis for electoral rights & $\begin{array}{c}\text { Existing national legislation before the } 1994 \\
\text { local elections directive }\end{array}$ \\
\hline Germany & Nationality & $\begin{array}{l}\text { The rights to vote and run for office are constitution- } \\
\text { ally reserved for German nationals (Article } 20 \text { and } \\
28[1] \text { of the Basic Law). }\end{array}$ \\
\hline Italy & Nationality & $\begin{array}{l}\text { The rights to vote and run for office are constitution- } \\
\text { ally reserved for Italian nationals (Articles } 48 \text { and 51). }\end{array}$ \\
\hline Belgium & Nationality & $\begin{array}{l}\text { The rights to vote and run for office are constitution- } \\
\text { ally reserved for Belgian nationals (Article } 4 \text { ). }\end{array}$ \\
\hline Luxembourg & Nationality & $\begin{array}{l}\text { The rights to vote and run for office are constitution- } \\
\text { ally reserved for Luxembourg nationals (Articles } 52 \\
\text { and 107). }\end{array}$ \\
\hline Greece & Nationality & $\begin{array}{l}\text { The rights to vote and run for office are constitution- } \\
\text { ally reserved for Greek nationals (Article 51). }\end{array}$ \\
\hline Austria & Nationality & $\begin{array}{l}\text { The rights to vote and run for office are constitution- } \\
\text { ally reserved for Austrian nationals. }\end{array}$ \\
\hline
\end{tabular}

failing to convince the group on the merits of their special circumstances, each reconsidered or dropped their demands. In the counterfactual "diplomacy 101" scenario, COREPER sans socialization, this behavior would remain anomalous.

Second, the alternative explanation would not hypothesize a maximalist interpretation of Article 8(b) establishing the principle of equal treatment between national and nonnational EU citizens in municipal elections. Given the sensitive domestic political issues concerning electoral and citizenship laws, ${ }^{83}$ as well as the unanimity decision-rule that applied here, one would expect a much wider acceptance of national derogation and exemption claims than resulted. In short, the "diplomacy 101" model would predict a tendency toward a least-common-denominator application of Article 8(b). But as I will show, explaining the bargaining behavior of the EU permreps as well as the (maximalist) outcome is not possible without reference to how standards of appropriateness and group-community norms to collectively legitimate arguments are an internalized part of COREPER's collective culture.

83. In fact, Eurobarometer data from this era show no issue-area where EU citizens opposed EU action more. Eurobarometer, No. 39, EC, DG X, 1993. Cited in Eurostat 1996, 241. For example:

Common foreign policy toward countries outside the EU

$\begin{array}{cc}\% \text { for } & \text { \% against } \\ 66 & 19 \\ 52 & 38\end{array}$
1999

Each citizen of a country in the EU should have the right to vote in the munici- $\quad 48 \quad 41$ pal elections of the country in which he/she is resident 


\section{Relevance of Scope Conditions}

The local elections case provides solid evidence for how scope conditions play a role in promoting socialization. The intensity dimension is seen in the complex linkages between local elections and the larger political stakes of implementing the necessary secondary legislation of the Maastricht Treaty on time. Specifically, the treaty set a 31 December 1994 deadline to reach agreement on the detailed implementation rules for local voting rights. There was a general perception of responsibility among the permreps to reach agreement on a directive that would become a key substantive component of the fledgling EU citizenship chapter agreed to at Maastricht. This sense of responsibility comes out clearly in content analysis of interviews with participants, who claimed there was a shared belief that if it was sent to the ministers they would either not reach agreement at all or would be unable to "contain" discussions for derogations. A protracted stalemate on local elections, a heated debate among the foreign ministers, or a substantively watered-down directive in the scope and terms of application were all scenarios that the EU permreps collectively wanted to avert. Within this context, negotiations were both intense and sustained, supporting Hypothesis 1 (that internalized group-community standards are more likely under such conditions).

The local elections case also illustrates the importance of the second background condition: insulation. In this instance, many of the permreps were instructed by their capital to keep negotiations at their level and avoid the GAC. One official claimed his ambassador's instructions clearly signaled the need to "keep it away from the press, where it would have been politicized quickly." ${ }^{84}$ Another explained, "We all knew that if the discussion was put a certain way we never would reach agreement. Because of the press, pressure from national populations, the idea that 'We will be run by foreigners.'" 85 This supports Stasavage's findings that insulated negotiations are a strategically rational institutional design where the risks of posturing run high. ${ }^{86}$ The high degree of insulation manufactured to help COREPER "find solutions" also clearly supports Hypothesis 2 (that internalized norms are more likely under such conditions). Indeed, insulation proved critical to the process of normative suasion, seen below in the use of "restricted" sessions to sort out whose pleas for special consideration warranted attention. The restricted ambassadors-only setting provided a degree of insulation for principled debate and deliberative argumentation that other Council bodies, especially the GAC, simply did not possess. 


\section{Negotiating Derogations: Collective Legitimation and the Principle of Equal Treatment}

The most critical stage of negotiations centered on who would receive derogations from the scope and application of the directive. The entire agreement hinged on this issue, because it would define how extensive coverage was and whether the principle of equal treatment would be interpreted in a maximal or minimal sense. When the ambassadors began derogation discussions in the fall of 1994, nearly half were under instruction to seek special consideration, although the presentation of these "special problems" would only be played out over the next seven weeks. In particular, six member states would claim serious domestic political difficulties: Luxembourg, Denmark, France, Greece, Austria, and Belgium. See Table 2.

Luxembourg received the earliest support for a derogation, and discussion reiterated why this was justified, given the high proportion of nonnational Community residents-nearly 30 percent of the total electorate. ${ }^{87}$ There was also the precedent of the 1993 directive on the right to vote in European Parliament elections, where Luxembourg was allowed to set minimum residency requirements of five years for nonnational EU voters and ten years for candidates. ${ }^{88}$ The agreed wording of the derogation covers a member state where nonnational EU citizens form more than 20 percent of the total electorate, effectively limiting the exemption to Luxembourg (that is, the 20-percent threshold is not applicable to individual municipalities within member states). But the Luxembourg exception did create a precedent that other delegations would try to extend to their own "special" problems in justifying a case for national derogations.

Denmark, for example, already allowed all foreign nationals the right to vote in local elections after a minimum residency of three years. They therefore wanted to extend this residency requirement to nonnational EU citizens as a special clause to the directive. But few supported a fixed residency requirement, under the logic that Danish nationals were not subject to the same restriction and, it was argued, this would violate the principle of equal treatment between national and nonnational EU citizens. ${ }^{89}$

Group discussion led to a consensus that equal treatment should not be enforced by sliding scale, whereas justification in the case of Luxembourg could be extended by varying degrees to other domestic contexts. ${ }^{90}$ This argument carried considerable persuasive power, and there is no evidence that Denmark put up much of a struggle after failing to sell their case in COREPER. The Danish ambassador kept

87. In the other member states, the average proportion of nonnational EU residents to nationals varied from 0.1 percent (Finland) to 6 percent (Belgium) of the electorate. See Lewis 1998, tab. 5-3, 222.

88. Council Directive 93/109/EC. Official Journal L 329/34, 30 December 1993. Following adoption of the EP voting directive, a number of researchers predicted the local elections directive would be more controversial. See, for example, Koslowski 1994, 389; and Oliver 1996, 475, 489.

89. Author's interview, 21 May 1996.

90. Author's interviews, 21 May 1996; 18 April 1997; and 18 May 2000. 
TABLE 2. Derogation arguments for the 1994 local elections directive

\begin{tabular}{ccc} 
Member state & $\begin{array}{c}\text { Persuasive } \\
\text { Nature of the problem }\end{array}$ & $\begin{array}{c}\text { Collectively legitimated } \\
\text { outcome }\end{array}$ \\
\hline
\end{tabular}

Luxembourg 30 percent of electorate are non- $\quad$ Yes national EU citizens.

$\begin{array}{ll}\text { Denmark } & \text { All foreign nationals can vote in } \\ \text { local elections after meeting a } \\ \text { residency requirement of three } \\ \text { years; Community nationals } \\ \text { should still be required to meet } \\ \text { this requirement. }\end{array}$

France Certain local offices participate in the Collège des grands électeurs sénatoriaux and have powers to elect delegates to the parliamentary assembly.

In municipalities where more than 20 percent of voters are nonnational EU citizens, only 20 percent of the seats in the local assembly should be held by such nationals.

Greece Desired extension of the Luxembourg derogation to the local level.

Austria Desired extension of the Luxembourg derogation to the local level.

Belgium

Territorial division of electorate into linguistic communities.
Article 12(1). May establish minimum residency requirements for nonnational EU citizens, not to exceed the term length of the local office in question (to vote) and twice the term length to stand as candidate.

No Danish nationals are not subject to this requirement; would violate the principle of equal treatment between all EU citizens.

Yes

Article 5(4). Allows additional restrictions on local offices designating delegates who vote in or elect members to the parliamentary assembly.

No Violates the principle of equal treatment, and the restriction of posts to own nationals in Article 5(3).

No

Exemptions should be as restricted as possible and are not applicable to local government units; the Luxembourg derogation applies to the national level.

No Exemptions should be as restricted as possible.

Yes

Article 12(2). May restrict application of directive to certain communes, a list of which must be published one year before elections are held.

the reservation on the table until the 7 December session of COREPER, neither removing the request for a residency requirement nor pushing very hard for amendment. Unable to convince others, the Danish delegation dropped their reserve and accepted the directive as it stood. Standard bargaining theory would have expected something different here, either a tacit or explicit linkage to the "shadow of the 
veto," or at minimum, a more visible cost-benefit analysis weighing an agreement with no residency requirements against the political difficulty of reforming national electoral and citizenship legislation. "Diplomacy 101" would also expect to find an active campaign by Denmark to support other delegations with similar preferences (especially France, Belgium, and possibly Greece and Austria).

France requested a derogation because of special problems in municipalities where mayors had authority to elect Senate delegates. Specifically, the French wished to exclude municipal offices with independent powers in Senate elections from the scope of the directive. Based on this argument, they received support and understanding in COREPER. The group's rationale for accepting the derogation was that Article $8 \mathrm{~b}(1)$ of the Maastricht Treaty clearly delimits the scope of voting and participatory rights to the municipal level.

In addition, the French made a second special request to restrict the directive's scope by limiting the number of local seats open to nonnational EU citizens in specific municipalities. In October, under pressure from Paris and the political signals being sent from the Senate, the French ambassador was instructed to argue for a clause limiting the number of seats open to other member states' citizens to 20 percent in municipalities where more than 20 percent of the electorate were nonnational EU citizens. ${ }^{91}$ The new French proposal suggested the following restriction:

In the basic local government units where the number of voters within the scope of Article 3 represents more than $20 \%$ of national voters, the Member State of residence may limit to this proportion the number of elected representatives who are nationals of other Member States authorized to sit in the assemblies of such local authorities. ${ }^{92}$

In practical terms, this would have extended the Luxembourg derogation to the local level. Greece showed early support for the idea, but the German, Portuguese, Spanish, Italian, and British delegations placed the "gravest reservations" on the proposal as a violation of the principle of equal treatment. ${ }^{93}$ In the course of discussing the "quota system" at several different meetings, a majority of ambassadors spoke in support of rejecting this argument, while others, including the French ambassador, remained silent. The ambassadors who found the French request unconvincing argued that the derogation would result in a patchy implementation of the directive and render the Treaty's objective of endowing EU citizenship with distinct rights a hollow shell. The French ambassador, under instruction, kept this reservation in place right up until the end, when it was dropped after the lunch session of COREPER on 7 December. ${ }^{94}$

91. Author's interview, 10 March 1997.

92. Council Document 8810/94, 7 September 1994, 8.

93. Author's interviews, 4 and 18 March 1997.

94. See discussion below. 
Why the French would drop this reserve requires a two-part explanation, of which neither part fits the standard negotiation story. First, the French ambassador became convinced that a maximal interpretation of equal treatment was essential and the quota system was incompatible with this concept. ${ }^{95}$ Second and more tellingly, the French ambassador then went "out on a limb" to convince foreign ministry superiors (who were well aware of the bellwether position of the Senate on nonnational citizenship rights) that the quota argument was unconvincing and lacked justification. ${ }^{96}$ Going one step further, below I track how the change in French position and quiet removal of the quota proposal, coupled with acceptance of others' derogation claims, shows a clear instance of Type II normative suasion.

Greece and Austria both experienced difficulties generating understanding for their special problems. Both arguments were rejected in COREPER, and each shows a dynamic of collective legitimation that the alternative explanation would miss because of the irreducible quality of communicative rationality involved. Nor can standard negotiation theory explain why the rejectees made no recourse to the "shadow of the veto." One rejection came informally and was essentially unspoken, while the other required a more dramatic technique. Raised initially at the working-group level and during informal bilateral talks, the Greek delegation voiced what one group member described as "their hypothetical concern that they could have the future obligation to give Turkish citizens the right to vote" should Turkey ever become an EU member state. ${ }^{97}$ But Greece never came out and made an argument for a derogation at the group level in COREPER. The Greeks, perhaps aware that their argument lacked persuasive power, quietly dropped their reserve.

A similar hypothetical concern was raised by Austria, but this time the group relied on a more explicit rejection from the presidency, then held by Germany, to delegitimize and even "shame" Austria's claim for special understanding. "They were afraid of how the directive would be accepted internally," a group representative recalled, "They are afraid of extreme Right movements and they have a high standard of living, so it was not easy to explain to them the advantage of the directive." 98 The Austrian ambassador pressed for a special derogation twice at the level of COREPER. The first time, no one said anything in reply. "We just sat there and listened," a participant recalled:

[German Ambassador] von Kyaw [as Chair] waited to see what would happen. But the second time Austria raised the issue, von Kyaw was very rough to the Austrian Permanent Representative. The Austrian Ambassador said in COREPER, "What is the logical argument why you cannot accept our case?" Von Kyaw replied very sharply, "We are here meeting very pragmatically, I 
don't have to explain the logical case to you." He said this very rough and it was the last we heard of the Austrian derogation. ${ }^{99}$

Interviews at Austria's permanent representation confirm that the group rejection was presented back in Vienna as a consensus among the other member states for a maximal interpretation of the directive's application, but that the group gave assurances that a review procedure would enable future reevaluation. ${ }^{100}$ Austria's "black eye" in this case is consistent with the delegation's reputation early in their membership for delivering rigid instructions and inflexible policy positions in Brussels.

It is plausible that differences between the Greek and Austrian appeals to the group were partly a function of the latter's noviceness (Austria joined the EU in January 1995). One large member state's ambassador with senior status among the group summarized Austria's behavior in this case as simply, "they were too new." ${ }^{101}$ The pattern evidenced here also lends support to Checkel's hypothesis that socialization is more likely when agents have fewer ingrained cognitive priors and beliefs that are inconsistent with the socializing agency's message. ${ }^{102}$ While it is important to avoid overstating the difference in tact by Greece and Austria, the internalized norms argument would account for the difference in argumentation by contrasting two delegations at very different stages of membership and degrees of internalization. ${ }^{103}$

The noviceness argument is also relevant for relating the differential behavior of Greece and Austria to what this volume calls role-playing (Type I) socialization. As Checkel explains, role-playing socialization involves a process whereby an agent learns new roles, acquiring the knowledge to act upon them. ${ }^{104}$ In this instance, one can code Austrian bargaining behavior as too new to act the role, compared to Greece's more cautious and informal probing of group support for some form of limited exemption. A key question for Type I socialization is how does one know what is a socially expected role in a given community setting? Austria's bargaining approach shows how such a learning process among newcomers might work in COREPER, and it represents an important learning experience for them to acquire the knowledge to act on a new role.

Whatever the case, the interviews consistently confirm that the group rejection of Austria's demand was a key delimiter in derogation negotiations. Indeed, from this point on, a maximal interpretation of equal treatment prevailed. For those who still had outstanding derogation claims-including Denmark, France, and Belgium, as well as Greece's hypothetical and as-yet informal request-the Austrian

99. Author's interview, 10 March 1997.

100. Author's interviews, 18 March 1996; and 10 May 1996.

101. Author's interview, by telephone to national capital, 22 April 2003.

102. See Checkel, this volume.

103. An irony here is that few EU specialists would code Greece as an exemplar at internalizing EU norms. For an argument that Greece is a laggard in adopting EU norms, see Marks 1997.

104. Checkel, this volume. 
rejection served as a marker for the standards by which derogation arguments would be measured.

The final "special" problem was raised by Belgium, which proved to be the endgame of derogation talks. Because of cleavages between the French, Dutch, and German language communities in Belgium, the directive had the potential to alter linguistic majorities within municipalities. ${ }^{105}$ Strategically, the Belgian delegation waited to present their case until the others' arguments had been heard. One ambassador recalled that the issue was "How to accept the Belgium problem without opening the Pandora's box of Treaty revision?" "We were able to do it in COREPER," he added, "but it would have been difficult to do in a crowded, mediacized General Affairs Council." 106

The Belgian ambassador requested a restricted session to clear the room and said, "We will need constitutional changes to transpose this directive and the Flemish Chamber will not accept it without a derogation." Unlike the other failed derogation arguments, the Belgian problem was justified with a persuasive argument, and one that genuinely convinced the others, even those who were initially skeptical. According to an ambassador from one of the large member states, "An example of persuasion and being convinced was the Belgian derogation on local elections. When I first read it, I thought, 'This is stupid.' But I became convinced they had a real problem there." 107

The Belgian derogation was settled the following week over lunch (on 7 December), again in the restricted, ambassadors-only format. The terms of the derogation are included as an annex to the directive. Specifically:

Belgium states that if it were to make use of the derogation provided for in Article 12(2) that derogation would be applied to only some of the local government units in which the number of voters within the scope of Article 3 exceeded $20 \%$ of all voters where the Belgian government regarded the specific situation as justifying an exceptional derogation of that kind. ${ }^{108}$

The 7 December lunch included a group discussion of how to explain the Belgian derogation to their capitals. As one participant explained, "we had a discussion of the type of arguments we could use back to our capitals to explain why this derogation was necessary." 109 The ambassadors from France and Denmark agreed to drop their requests for exemption. The Greek and Austrian delegates remained quiet. Portugal's ambassador also expressed confidence that Lisbon would agree to abstain, despite instructions to reject any derogation. Before restarting COREPER after lunch, the ambassadors each telephoned their foreign ministers to explain the agreement reached.

106. Author's interview, 18 March 1997.

107. Author's interview, 18 May 2000.

108. Official Journal L 386/47, 31 December 1994.

109. Ibid. 
The trickiest conversations were with Paris and Lisbon. The French ambassador used his considerable seniority to convince his foreign minister that the directive was acceptable. Likewise, the Portuguese ambassador sold the compromise reached in COREPER, but only after a lengthy conversation with his foreign minister. In this case, the minister and ambassador agreed that dissatisfaction with the extent of derogations did not warrant the use (or threat) of veto, but instead it was decided that Portugal would abstain. ${ }^{110}$ Portugal's abstention, rather than use (or threat) of the veto, shows how informal norms such as diffuse reciprocity operate in the context of COREPER's institutional environment and how they can promote pro-norm behavior. Portugal's carefully weighted decision to abstain following detailed communications between the ambassador and foreign minister also displays evidence of what this volume calls strategic calculation. Specifically, the abstention was a creative solution to signal a difference of view while conforming to normative standards and the reasoned consensus, and in the process generating potential "social capital" for the future. Abstaining, in this framework of meaning, is a "self-binding" form of restraint that can contribute to one's social influence.

\section{Alternative Explanations Revisited: Internalized Norms or Diplomacy 101 ?}

Critical to showing that this goes beyond simple negotiation theory, I found ample evidence of how group discussions collectively legitimated some arguments while rejecting others. The group actively persuaded delegations with derogation instructions to accept a strong interpretation of the principle of equal treatment. In some cases persuasion was informal and bilateral, in others it was via strategic interventions of the German presidency, and sometimes (as in the case of Austria), this persuasion was at the collective COREPER level.

As negotiations reached their final stages, the issue of how to handle the Belgian argument was contained within COREPER's institutionalized remit to find solutions. This differs from the standard logic of two-level games analysis (that is, Belgium shows they have "tied hands" to gain a dispensation) because of the socialization component involved. Without the collective legitimation of derogation claims by group-community standards, one would have expected the principled commitment to equal treatment of national and nonnational EU citizens to unravel at this stage because of recourse to the veto and the capacity of veto threats to become credibly linked to the Belgian exception. If this were all about instrumental rationality, relative power, and the formal decision-rule, one would have expected a

110. As one of the largest "exporters" of EU citizens, Portugal preferred no derogations beyond the Luxembourg exception. As such, the Portuguese were skeptical of both the French concession regarding scope and the limited territorial application for Belgium. An official at Portugal's permrep explained that the abstention "was an elegant way to live with the text. It was a special way to avoid disagreement, but to make a political gesture." Author's interview, 10 March 1997. 
style of brinkmanship by Denmark, France, Greece, and Austria as the Belgian issue lurked in the background and the 31 December deadline loomed. In short, one would have seen a different outcome. As the participants saw it, the Belgian problem lurked in the background even before the Belgian ambassador asked for a partial, flexible derogation; the issue was more how to justify the Belgian exception without opening the Pandora's box of special dispensations for any member with sensitive national concerns. Reaching a normative consensus on acceptable derogations was based on group-community standards of fairness, and included obligations of appropriate self-restraint for those delegations who lacked persuasive arguments (which helps account for the complete lack of veto threats, even among "exporter" states such as Portugal).

In the case of Austria's argument, the instrumental rationale ("Why can't the group explain the logical case to us") not only failed, but group norms were used to shame the Austrian position and delegitimize the argument as unacceptable. The Belgian ambassador, widely considered the doyen of COREPER during the late 1980s and 1990s, used his considerable argumentative resources to convince the others that the derogation would be of a closed nature, and used as sparingly as possible. The Belgian derogation unambiguously demonstrates the power of persuasion and role of argumentative rationality in everyday EU decision making: a small state with a "good" argument convinced the others, some of whom were initially skeptical, to accept their claim and in a few cases "go out on a limb" to sell the agreed results back home to the capital.

The local elections example thus offers empirical support for the internalized norms argument, and the case evidence displays both Type I and Type II characteristics. Type I internalization-rule-following behavior based on socially expected standards ${ }^{111}$ — can be seen in the way those with unconvincing derogation claims dropped their demands. This includes Denmark, Greece, Austria, and France on quotas. Evidence of Type I internalization can also be seen in the nonaction of "exporter" states such as Portugal, who logically preferred no derogations at all, but displayed none of the instrumental calculative reasoning (including any hint of recourse to veto rights) that would be expected in the standard bargaining explanation. Portugal's abstention is more consistent with the logic of appropriateness and socially accepted standards to avoid blockage of the group's "reasoned consensus" around partial, limited exemption for Belgium, France (on mayoral candidates), and Luxembourg.

Type II internalization-accepting group-community standards as "the right thing to do" 112 - is evidenced by the "reasoned consensus" legitimating Belgium's plea for special consideration. The strongest evidence of Type II normative suasion can be seen in the actions of the French ambassador. Carefully triangulated interview histories support a characterization that he was genuinely persuaded by his Bel-

111. See Checkel, this volume.

112. Ibid. 
gian colleague's argument, after initial doubts, and then went on to convince his superiors in Paris to accept Belgium's partial exemption while at the same time dropping the French preference for a quota system. According to the key participants involved, this action was premised on becoming convinced that helping Belgium was the right thing to do. As one ambassador put it, "we found understanding in our capitals ... in the end we persuaded our governments, we did it very much for Belgium." 113

In summary, the local elections case offers evidence that COREPER socialization affects not only strategies, but also conceptions of the self. Evidence of an expanded conception of the self, in which permreps practice internalized groupcommunity standards based on a noncalculative logic of appropriateness, can be seen in both the bargaining behavior and outcome of the local elections case. The interview and case-study data offer confirming evidence for the four socialization measures discussed in section two. First, I have shown noninstrumental selfrestraint among several delegations after they failed to convince the others of their argument (including Denmark, France, and Greece). Second, there were numerous examples of self-enforcing adherence to informal norms, such as the "self-control" of derogation claimants to not explicitly reference veto options or drop reserves based on favorable cost-benefit ratios. Third, evidence of empathy and otherregarding behavior not linked to calculative reasoning can be seen in the "reasoned consensus" to legitimate Belgium's derogation claim even though several ambassadors had to sell the validity of Belgium's case to their superiors while dropping their own claims. Fourth, and finally, this case illustrates the limits on instrumentalism through the collective legitimation of arguments. Restricted sessions were used to collectively accept and reject derogation claims (and "plot" ways to sell the Belgian derogation to ministers) around a shared understanding of maximal interpretation of equal treatment. As a result, the internalized norms argument can more fully account for the way in which Denmark, France, and Greece quietly dropped, or chose not to articulate, derogation claims than can "diplomacy 101." More dramatically, the group rejection of Austria's claim demonstrates how collective legitimation places limits on instrumental behavior by signaling that certain behavior is just not acceptable. In sum, the constructivist logic of internalized norms can better account for both the bargaining behavior and outcomes of the local elections case than the rationalist logic of consequences alone.

\section{Conclusion: Blurring the National and the European}

COREPER's institutional architecture challenges the conventional dichotomy that sharply demarcates the national and European levels. As a collectivity of memberstate representatives, COREPER exemplifies the imagery of national and Euro- 
pean levels of governance becoming amalgamated. ${ }^{114}$ Accordingly, COREPER's Janus-like design is an anomaly for theorists who draw rigid distinctions between "national" and "supranational" agency. For example, in one prominent account of European integration, the corporate body of "supranational entrepreneurs" in the EU is effectively limited to European Commissioners. ${ }^{115}$ But the EU permreps belie such a straightforward pigeonhole. As Wallace puts it, "It would be a caricature of this intricate policy process to counterpose national actors and supranational entrepreneurs as separate elites, promoting opposed interests." 116 The permreps who participate in weekly COREPER negotiations and share a collective responsibility to maintain the output of the Council as a whole, nicely illustrate how the logics of consequences and appropriateness can interface, which in turn suggests that national and supranational identifications can become complexly intertwined. According to March and Olsen, "Political actors ... calculate consequences and follow rules, and the relationship between the two is often subtle." 117

Perhaps surprisingly, permreps do not self-reflectively see these as competitive or contradictory role/identity sets. My findings are somewhat at odds with others in this volume, such as Beyers and Hooghe, who offer clear-cut evidence of ranked "primary" and "secondary" allegiances among EU officials. ${ }^{118}$ A major difference, of course, is the point of reference: they are examining the administrative expert level of Council working groups and Commission officials, and both of these display qualitative differences from COREPER in scope conditions as well as what Egeberg refers to as "organizational characteristics." 119

The testimonies of the permreps interviewed for this project suggest that identities and role conceptions are not so clearly juxtaposed at this level of the EU system. Overall, the evidence points to a pattern of symbiosis between national and collective identities. ${ }^{120}$ The EU permreps have operationalized the concept of "double-hatting." ${ }^{121}$ Instead of limited notions of shifts and transfers of identity, or clearly juxtaposed primary and secondary affiliations, what one sees in COREPER is a cognitive blurring of the sharp definitional boundaries between the national and the European. None of this implies national identities are becoming marginalized; rather, what stands out is the interpenetration of the national

114. H. Wallace 2000, 7.

115. Moravcsik 1998, 54-60, 479-85.

116. W. Wallace 2000, 529-30.

117. March and Olsen 1998, 952.

118. See Beyers, this volume; and Hooghe, this volume. See also Egeberg 1999; and Egeberg, Schaefer, and Trondal 2003.

119. Egeberg 2004.

120. The symbiosis analogy is a trademark of some of the subtler findings (now often overlooked) in the early neofunctionalist literature on the ECSC and EEC. See Haas 1958, 526; and Lindberg and Scheingold 1970, 94-95.

121. See Laffan $2004,90-94$, for a conceptual discussion of "double hatting" among Council actors. I also thank the editors for suggesting this point. 
with the European and vice versa. ${ }^{122}$ The identity configuration of the EU permreps is compatible with what Risse suggestively describes as a "marble cake" concept of multiple identities, in which "the various components of an individual's identity cannot be neatly separated on different levels." ${ }^{123}$ On this reading, an actor's "identity components influence each other" and "mesh and blend." ${ }^{124}$ Nor does this in any way imply that socialization effects are homogenous. ${ }^{125}$ A more systematic study of socialization processes in COREPER would build controls into the model for variation caused by preexisting differences in member states' European policy, administrative culture, and policy styles. ${ }^{126}$

Finally, it is worth further consideration how the socialization effects identified in this article are potentially reversible. That is to say, the Brussels-based culture of decision making, endowed with dense informal norms and standards of appropriateness, could be undone. First, there is little, if any, evidence to support a "holistic" internalization thesis in which norm compliance becomes automatic. ${ }^{127}$ Rather, COREPER socialization is a process of incremental, partial internalization. This point is evidenced more clearly in my larger multiple-case-study project, where the British, for example, display a more a la carte adherence to informal norms when there are principled objections to EU policies (as in social policy). ${ }^{128}$

This study did find hard evidence of Type II internalization, ${ }^{129}$ particularly in the way those with rejected derogation claims convinced their capitals and/or "went out on a limb" to secure the Belgian derogation once a "reasoned consensus" was reached in COREPER - contrary to what standard bargaining theory and instrumental cost-benefit predictions would have expected. But it does not necessarily follow that a switch from a logic of consequences is complete: just ask the British if they could find someone else's argument on fiscal federalism convincing, or the French if policy toward the Middle East is open to EU deliberation and collective legitimation norms. In other words, it would be inaccurate to characterize the internalization of group-community standards as "taken-for-granted" in a holistic sense, but the bargaining behavior and decisional outcomes documented in this article do consistently confirm instances of pro-norm behavior as the "right thing to do."

Second, it is possible to imagine scenarios in which the scope conditions for this socialization story were fundamentally altered: either the density of issue coverage (for example, due to the increased fragmentation of preparatory authority

122. For a conceptualization of how "the European dimension is included in national selfconceptions," see Waever 1995, 412, 430. For a detailed case study on Germany, see Katzenstein 1997.

123. Risse 2004, 251.

124. Ibid., 251-52.

125. See Legro 1997 for a discussion of how pro-norm behavior may exist in "varying strengths" within a given community.

126. For a detailed analysis of how socialization is affected by domestic organizational embeddedness, see Beyers, this volume.

127. On "holistic" internalization, see Hurd 1999, 398.

128. Lewis 1998.

129. See Checkel, this volume. 
among rival committees) or insulation (for example, because of domestic political pressures to address the "democratic deficit" and increase transparency). Changing the scope conditions would likely alter what neofunctionalists called l'engrenage effects, ${ }^{130}$ and it is quite possible that the standards of appropriateness would be altered as a result. Under altered background conditions or changes in the standards of appropriateness, ${ }^{131}$ one would expect the identity configuration of EU permreps to revert to more egoistic and instrumental variants. Under such conditions, pro-norm behavior would become contingent on more explicit and regularized calculation, and agents might use voting weights and veto threats rather than appeals to fairness or principled debate that would, over time, affect the perceived legitimacy of the EU's collective decision-making culture.

\section{References}

Bjurulf, Bo, and Ole Elgström. 2004. Negotiating Transparency: The Role of Institutions. Journal of Common Market Studies 42 (2):249-69.

Bostock, David. 2002. COREPER Revisited. Journal of Common Market Studies 40 (2):215-34.

Butler, Michael. 1986. Europe: More Than a Continent. London: William Heinemann.

Council of the European Union. 1997. Council Guide, Volume II: Comments on the Council's Rules of Procedure, Sept 1996. Luxembourg: Office for Official Publications of the European Communities.

De Wilde d'Estmael, Tanguy, and Christian Franck. 1996. Belgium. In The European Union and Member States: Towards Institutional Fusion?, edited by Dietrich Rometsch and Wolfgang Wessels, 37-60. Manchester, England: Manchester University Press.

Dinan, Desmond, ed. 1998. Encyclopedia of the European Union. Boulder, Colo.: Lynne Rienner.

Egeberg, Morten. 1999. Transcending Intergovernmentalism? Identity and Role Perceptions of National Officials in EU Decision Making. Journal of European Public Policy 6 (3):456-74.

. 2004. An Organisational Approach to European Integration: Outline of a Complementary Perspective. European Journal of Political Research 43 (2):199-219.

Egeberg, Morten, Günther Schaefer, and Jarle Trondal. 2003. The Many Faces of EU Committee Governance. West European Politics 23 (3):19-40.

$\rightarrow$ Eising, Rainer. 2002. Policy Learning in Embedded Negotiations: Explaining EU Electricity Liberalization. International Organization 56 (1):85-120.

Eurostat, Statistical Office of the European Communities. 1996. Social Portrait of Europe. Luxembourg: Office for Official Publications of the European Communities.

Evans, Peter. 1993. Building an Integrative Approach to International and Domestic Politics: Reflections and Projections. In Double-Edged Diplomacy: International Bargaining and Domestic Politics, edited by Peter Evans, Harold Jacobson, and Robert Putnam, 397-430. Berkeley: University of California Press.

$\rightarrow$ Golub, Jonathan. 1999. In the Shadow of the Vote? Decision Making in the European Community. International Organization 53 (4):733-64.

Gomez, Ricardo, and John Peterson. 2001. The EU's Impossibly Busy Foreign Ministers: 'No One is in Control.' European Foreign Affairs Review 6 (1):53-74.

130. Roughly translated, l'engrenage means "getting caught up in the gears." See Dinan 1998, 166.

131. Could enlargement change expectations of collective legitimation and group-community norms? Many Brussels insiders see the EU-25 as a qualitative leap in heterogeneity that will have unintended consequences for the Council's everyday decision-making environment. 
Haas, Ernst. 1958. The Uniting of Europe: Political, Social, and Economic Forces, 1950-1957. Stanford, Calif.: Stanford University Press.

Hayes-Renshaw, Fiona, and Helen Wallace. 1995. Executive Power in the European Union: The Functions and Limits of the Council of Ministers. Journal of European Public Policy 2 (4):559-82.

- 1997. The Council of Ministers. New York: St. Martin's Press.

Hurd, Ian. 1999. Legitimacy and Authority in International Politics. International Organization 53 (2):379-408.

Iklé, Fred Charles. 1964. How Nations Negotiate. New York: Harper \& Row.

Joerges, Christian, and Ellen Vos, eds. 1999. EU Committees: Social Regulation, Law, and Politics. Portland, Ore.: Hart.

Jones, Bernie. 1994. A Comparison of Consensus and Voting in Public Decision Making. Negotiation Journal 10 (2):161-72.

Jupille, Joseph, James Caporaso, and Jeffrey Checkel. 2003. Integrating Institutions: Rationalism, Constructivism, and the Study of the European Union. Comparative Political Studies 36 (1/2):7-41.

Kahler, Miles. 1995. International Institutions and the Political Economy of Integration. Washington, D.C.: Brookings Institution Press.

Katzenstein, Peter. 1997. United Germany in an Integrating Europe. In Tamed Power: Germany in Europe, edited by Peter Katzenstein, 1-48. Ithaca, N.Y.: Cornell University Press.

Keohane, Robert. 1984. After Hegemony: Cooperation and Discord in the World Political Economy. Princeton, N.J.: Princeton University Press.

- 1986. Reciprocity in International Relations. International Organization 40 (1):1-27.

Kerremans, Bart. 1996. Do Institutions Make a Difference? Non-Institutionalism, Neo-Institutionalism, and the Logic of Common Decision-Making in the European Union. Governance 9 (2):217-40.

Koslowski, Rey. 1994. Intra-EU Migration, Citizenship and Political Union. Journal of Common Market Studies 32 (3):369-402.

Kramer, Roderick, and David Messick, eds. 1995. Negotiation as a Social Process. London: Sage.

Laffan, Brigid. 2004. The European Union and Its Institutions as "Identity Builders." In Transnational Identities: Becoming European in the EU, edited by Richard Herrmann, Thomas Risse, and Marilynn Brewer, 75-96. Lanham, Md.: Rowman and Littlefield.

Lax, David, and James Sebenius. 1986. The Manager as Negotiator: Bargaining for Cooperation and Competitive Gain. New York: Free Press.

Legro, Jeffrey. 1997. Which Norms Matter? Revisiting the Failure of Internationalism. International Organization 51 (1):31-63.

Lewis, Jeffrey. 1998. Constructing Interests: The Committee of Permanent Representatives and DecisionMaking in the European Union. Ph.D. diss., University of Wisconsin-Madison.

- 2000. The Methods of Community in EU Decision-Making and Administrative Rivalry in the Council's Infrastructure. Journal of European Public Policy 7 (2):261-89.

- 2002. National Interests: COREPER. In The Institutions of the European Union, edited by John Peterson and Michael Shackleton, 277-98. Oxford: Oxford University Press.

- 2003. Institutional Environments and Everyday EU Decision Making: Rationalist or Constructivist? Comparative Political Studies 36 (1/2):97-124.

Lindberg, Leon, and Stuart Scheingold. 1970. Europe's Would-Be Polity: Patterns of Change in the European Community. Englewood Cliffs, N.J.: Prentice-Hall.

March, James, and Johan Olsen. 1998. The Institutional Dynamics of International Political Orders. International Organization 52 (4):943-69.

Marks, Michael. 1997. Moving at Different Speeds: Spain and Greece in the European Union. In Tamed Power: Germany in Europe, edited by Peter Katzenstein, 142-66. Ithaca, N.Y.: Cornell University Press.

Moravcsik, Andrew. 1998. The Choice for Europe: Social Purpose and State Power from Messina to Maastricht. Ithaca, N.Y.: Cornell University Press.

Noël, Emile. 1967. The Committee of Permanent Representatives. Journal of Common Market Studies 5 (3):219-51. 
Oliver, Peter. 1996. Electoral Rights Under Article 8B of the Treaty of Rome. Common Market Law Review 33 (3):473-98.

Pruitt, Dean. 1981. Negotiation Behavior. New York: Academic Press.

Puetter, Uwe. 2003. Informal Circles of Ministers: A Way Out of the EU's Institutional Dilemmas? European Law Journal 9 (1):109-24.

$\rightarrow$ Putnam, Robert. 1988. Diplomacy and Domestic Politics: The Logic of Two-Level Games. International Organization 42 (3):427-60.

1993. Making Democracy Work: Civic Traditions in Modern Italy. Princeton, N.J.: Princeton University Press.

Raiffa, Howard. 1982. The Art and Science of Negotiation: How to Resolve Conflict and Get the Best Out of Bargaining. Cambridge, Mass.: Harvard University Press.

Rapoport, Anatol. 1960. Fights, Games, and Debates. Ann Arbor: University of Michigan Press.

$\rightarrow$ Risse, Thomas. 2000. 'Let's Argue!': Communicative Action in World Politics. International Organization 54 (1):1-39.

. 2004. European Institutions and Identity Change: What Have We Learned? In Transnational Identities: Becoming European in the EU, edited by Richard Herrmann, Thomas Risse, and Marilynn Brewer, 247-71. Lanham, Md.: Rowman and Littlefield.

Rubin, Jeffrey, and Frank Sander. 1988. When Should We Use Agents?: Direct vs. Representative Negotiation. Negotiation Journal 4 (4):395-401.

Schimmelfennig, Frank. 2000. International Socialization in the New Europe: Rational Action in an Institutional Environment. European Journal of International Relations 6 (1):109-39.

$\rightarrow$ Stasavage, David. 2004. Open-Door or Closed Door? Transparency in Domestic and International Bargaining. International Organization 58 (4):667-703.

Strauss, Anselm. 1978. Negotiations: Varieties, Contexts, Processes, and Social Order. San Francisco: Jossey-Bass.

Trondal, Jarle. 2001. Administrative Integration Across Levels of Governance: Integration Through Participation in EU Committees. ARENA Report No. 01/7. Oslo, Norway: ARENA Centre for European Studies, University of Oslo.

2002. Beyond the EU Membership-Non-Membership Dichotomy? Supranational Identities among National EU Decision-Makers. Journal of European Public Policy 9 (3):468-87.

Van Schendelen, M. P. C. M. 1996. 'The Council Decides': Does the Council Decide? Journal of Common Market Studies 34 (4):531-48.

Waever, Ole. 1995. Identity, Integration and Security: Solving the Sovereignty Puzzle in EU Studies. Journal of International Affairs 48 (2):389-431.

Wallace, Helen. 1973. National Governments and the European Communities. London: Chatham House. . 2000. The Institutional Setting: Five Variations on a Theme. In Policy-Making in the European Union, 4th ed., edited by Helen Wallace and William Wallace, 3-37. Oxford: Oxford University Press.

Wallace, William. 1994. Regional Integration: The West European Experience. Washington, D.C.: Brookings Institution Press.

- 2000. Collective Governance. In Policy-Making in the European Union, 4th ed., edited by Helen Wallace and William Wallace, 523-42. Oxford: Oxford University Press.

Walton, Richard, and Robert McKersie, eds. 1965. A Behavioral Theory of Labor Negotiations: An Analysis of a Social Interaction System. New York: McGraw-Hill.

Wendt, Alexander. 1999. Social Theory of International Politics. Cambridge: Cambridge University Press.

Zartman, William, and Maureen Berman. 1982. The Practical Negotiator. New Haven, Conn.: Yale University Press. 